\title{
FAKTOR-FAKTOR YANG MEMPENGARUHI MINAT MAHASISWA MEMILIH PERGURUAN TINGGI EKONOMI ISLAM (STUDI KASUS : STEI SEBI)
}

\author{
Hadiyati Fitria \\ (Alumni STEI SEBI) \\ \& \\ Endang Ahmad Yani \\ (Dosen STEI SEBI)
}

\begin{abstract}
ABSTRAK
Tujuan penelitian ini adalah untuk mengetahui faktor-faktor apa saja yang mempengaruhi minat tersebut, dan faktor apa saja yang paling dominan berpengaruh terhadap minat mahasiswa.Pengolahan data dalam penelitian ini menggunakan metode analisischi-square yang diolah melalui software SPSS 16.0 for windows.Berdasarkan penelitian tersebut diketahui bahwa nilai $\mathrm{X}^{2}$ hitung lebih lebih besar dari $\mathrm{X}^{2}$ tabel, sehingga terdapat hubungan antara indikator motivasi, keinginan mempelajari Ekonomi Islam, citacita menjadi ahli Ekonomi Islam, beasiswa dan citra kampus terhadap kepuasan minat mahasiswa. Setelah melakukan analisis terhadap data yang diperoleh dari responden, maka peneliti menyimpulkan bahwa faktor dominan yang memiliki hubungan denganminat mahasiswa adalah faktor promosi motivasi dan keinginan mempelajari Ekonomi Islam dengan nilai $\mathrm{X}^{2}$ hitung masing-masing 25,998 dan 25,287.

Dari penelitian ini, dapat diperoleh informasi bahwa STEI SEBI sebagai lembaga pendidikan yang konsen dalam bidang Ekonomi Islam hendaknyadapat meningkatkan kualitas dalam kegiatan belajar dan mengajar, karena minat mahasiswa mempelajari ilmu Ekonomi Islam menjadi daya tarik utama disamping indikator lain seperti kesempatan mendapat beasiswa maupun citra kampus yang baik.
\end{abstract}

\section{Kata Kunci: Minat mahasiswa, perguruan tinggi Ekonomi Islam}

\begin{abstract}
ABSTRAC
The purposes of this study determine the factor that influence these interest and what factors are the most dominance influence on student interest. Data processing in this study will use chi square analysis method that be processed through software SPSS 16.0 for windows. Based on in these studies was discovered that value of X2 count bigger than X2 Table, so there will correlation between indicator of motivation, desire to learn Islamic Economy, dream of being an expert in Islamic Economic, scholarship and college image toward the satisfaction of student interest. After conducting an analysis data from respondents, so researcher would concluded that the dominance factor which have related with student interest were the factor of motivation promotion and
\end{abstract}


desire to learn Islamic Economic with value X2 count each 25.998 and 25.287. From this study, it can be obtained information that STEI SEBI as an educational institution concerned about Islamic Economic should improve quality in learning activities and teaching, because the interest of student to learn Islamic Economic science become main attraction beside other indicators such as opportunity to get a scholarship as well as better in campus image.

Keyword : Student Interest, Islamic Economic College

\section{PENDAHULUAN}

\section{Latar Belakang}

Praktik Perbankan Syariah direalisasikan dalam dunia Islam pertama kali pada tahun 1967 dengan didirikannya Mith Ghamr dalam Bank Mesir yang dipelopori oleh para pelaku bisnis dari kalangan jama'ah Ikhwanul Muslimin. Dalam perkembangannya, bank ini tidak berumur panjang akibat konflik politik antara jamaah tersebut dengan pemerintah Mesir. Namun ia merupakan tonggak dan pelopor yang kemudian memberikan inspirasi pada berbagai praktik perbankan sesuai dengan prinsip-prinsip syariah di negara lainnya. Pada tahun 1975 didirikan Islamic Development Bank yang operasionalnya dimaksimalkan sesuai dengan prinsip-prinsip syariah dengan tujuan meningkatkan kesejahteraan negara Islam diseluruh dunia. Sehingga dari awal tahun 1980-an hingga awal tahun 1990-an praktek perbankan syariah menyebar di hampir seluruh negeri Muslim. (Ali Sakti, 2007, hal. 287-288).

Menyoroti perkembangan dunia perbankan di Indonesia, diawali dengan berdirinya Bank Muamalat Indonesia pada 1 November 1991 dan mulai beroperasi pada 1 Mei 1992. Kemudian mulai diterapkan secara meluas oleh berbagai institusi perbankan baik yang memang murni syariah maupun bank yang menerapkan dual banking system sejak tahun 1998 dimana terjadi krisis ekonomi di Indonesia, dan sebagai respon positif terhadap UU No. 10 tahun 1998 yang memberi peluang perbankan untuk melayani transaksi syariah. Pengaturan perbankan syariah pun menjadi lebih spesifik dengan disahkannya UU No. 21 Tahun 2008 tentang perbankan syariah sehingga dunia perbankan syariah terus mengalami perkembangan positif.

Dunia perbankan terus tumbuh dan berkembang hingga sekarang, salah satunya terlihat dari jumlah Bank Umum Syariah (BUS) yang semakin banyak beroperasi, begitu pula dengan pertumbuhan Bank Perkreditan Rakyat Syariah (BPRS), seperti yang diperlihatkan tabel berikut: 
Tabel 0.1

Jumlah BUS, UUS dan BPRS

\begin{tabular}{|c|c|c|c|c|c|c|}
\hline $\begin{array}{l}\text { Kelompok } \\
\text { Bank \& LKS }\end{array}$ & 2007 & 2008 & 2009 & 2010 & 2011 & 2012 \\
\hline $\begin{array}{l}\text { Bank Umum Syariah } \\
\text { - Jumlah Bank } \\
\text { - Jumlah Kantor }\end{array}$ & $\begin{array}{l}3 \\
401\end{array}$ & $\begin{array}{l}5 \\
581\end{array}$ & $\begin{array}{l}6 \\
711\end{array}$ & $\begin{array}{l}11 \\
1,215\end{array}$ & $\begin{array}{l}11 \\
1,401\end{array}$ & $\begin{array}{l}11 \\
1,745\end{array}$ \\
\hline $\begin{array}{|ll|}\text { Unit Usaha Syariah } \\
\text { - } & \text { Jumlah Bank Umum } \\
& \text { Konvensional yang } \\
& \text { memiliki UUS } \\
- & \text { Jumlah Kantor }\end{array}$ & $\begin{array}{l}26 \\
196\end{array}$ & $\begin{array}{l}27 \\
241\end{array}$ & $\begin{array}{l}25 \\
287\end{array}$ & $\begin{array}{l}23 \\
262\end{array}$ & $\begin{array}{l}24 \\
336\end{array}$ & $\begin{array}{l}24 \\
517\end{array}$ \\
\hline $\begin{array}{ll}\text { Bank } & \text { Pembiayaan } \\
\text { Rakyat Syariah } \\
-\quad & \text { Jumlah Bank } \\
- & \text { Jumlah Kantor }\end{array}$ & $\begin{array}{l}\mathrm{a} \\
114 \\
185\end{array}$ & $\begin{array}{l}131 \\
202\end{array}$ & $\begin{array}{l}138 \\
225\end{array}$ & $\begin{array}{l}150 \\
286\end{array}$ & $\begin{array}{l}155 \\
364\end{array}$ & $\begin{array}{l}158 \\
401\end{array}$ \\
\hline Total & 925 & 1187 & 1392 & 1947 & 2291 & 2856 \\
\hline
\end{tabular}

Sumber : Statistik Perbankan Syariah (http://www.bi.go.id/web/id/, Desember 2012)

Tabel di atas menunjukkan bahwa lembaga keuangan syariah di Indonesia terus mengalami pertumbuhan. Secara umum, pada tahun 2007 ke tahun 2008 terjadi kenaikan sebesar 28\%, pada tahun berikutnya turun menjadi 17\%. Kenaikan yang cukup besar terjadi pada tahun 2009 ke tahun 2010 yakni sebesar 40\%. Tapi kemudian mengalami penurunan di tahun berikutnya menjadi 18\% dan terakhir pada tahun 2011 ke 2012 naik menjadi $25 \%$. Melihat fenomena fluktuasi tersebut, secara umum dapat dikatakan bahwa ekonomi Islam di Indonesia terus mengalami perkembangan.

Selain itu, peningkatan total aset perbankan syariah di Indonesia juga semakin baik, dari total aset pada tahun 2011 sebesar Rp. 104 Triliun, menjadi Rp. 155,66 Triliun per-Juli 2012. Pertumbuhan perbankan syariah mencapai 40,2\% dalam kurun waktu 5 tahun terakhir, dibandingkan dengan bank konvensional, ini sudah termasuk tinggi dimana bank konvensional hanya mencapai 16,7 \% dalam kurun waktu yang sama (Bank Indonesia, 2013).

Peran bank dan lembaga keuangan syariah itu sendiri dalam perekonomian di Indonesia menjadi hal yang sangat penting, melalui berbagai macam produknya yang dapat menghidupkan sektor riil sehingga roda perekonomian negara terus berjalan dan mampu membangun bangsa secara merata di segala bidang. Terlebih melalui 
peran lembaga keuangan mikro syariah yang dapat menjangkau masyarakat menegah ke bawah.

Namun, jika kita mengkaji lebih dalam akan ditemukan beberapa kendala bagi bank maupun lembaga keuangan syariah untuk berkembang pesat, salah satu kendala tersebut adalah ketersediaan Sumber Daya Manusia (SDM) yang ahli di bidang ekonomi syariah. Menggarisbawahi pada kendala tersebut, yakni keterbatasan SDM yang benar-benar memahami dan ahli di bidangnya merupakan salah satu aspek yang amat krusial, karena tanpa SDM yang paham dan ahli, kegiatan pengelolaan bank syariah akan terhambat atau bahkan terjadi banyak kekeliruan yang fatal sehingga kepercayaan nasabah yang notabene masih dalam proses pengenalan sistem syariah ini menjadi berkurang atau bahkan hilang. Hal ini tentu mengancam keberlangsungan bank syariah itu sendiri. Berikut data perkembangan jumlah SDM yang bekerja di bank dan lembaga keuangan syariah.

Tabel 0.2

Jumlah Pekerja di Bank dan Lembaga Keuangan Syariah

\begin{tabular}{|l|l|l|l|l|l|l|}
\hline $\begin{array}{l}\text { Kelompok Bank \& } \\
\text { LKS }\end{array}$ & $\mathbf{2 0 0}$ & $\mathbf{2 0 0 8}$ & $\mathbf{2 0 0 9}$ & $\mathbf{2 0 1 0}$ & $\mathbf{2 0 1 1}$ & $\mathbf{2 0 1 2}$ \\
\hline $\begin{array}{l}\text { Bank Umum } \\
\text { Syariah }\end{array}$ & 4,31 & 6,609 & 10,348 & 15,224 & 21,820 & 24,111 \\
\hline Unit Usaha Syariah & 2,26 & 2,562 & 2,296 & 1,868 & 2,067 & 3,108 \\
\hline $\begin{array}{l}\text { Bank Perkreditaan } \\
\text { Rakyat Syariah }\end{array}$ & 2,10 & 2,581 & 2,799 & 3,172 & 3,773 & 4,359 \\
\hline \multicolumn{1}{|c|}{ Total } & 8,68 & 11,752 & 15,443 & 20,264 & 27,660 & 31,578 \\
\hline
\end{tabular}

Sumber : Statistik Perbankan Syariah (http://www.bi.go.id/web/id/, Desember 2012)

Berdasarkan tabel,secara umum kita bisa melihat bahwa trend kenaikan jumlah SDM tahun 2007 ke tahun 2008 sebesar 35\%, kemudian turun menjadi $31 \%$ ditahun berikutnya dengan persentase yang sama sampai pada tahun 2010. Padahal pada tahun tersebut jumlah bank dan lembaga keuangan syariah mengalami kenaikan yang cukup signifikan yakni $40 \%$. Kemudian jumlah SDM baru mencapai kenaikan menjadi $36 \%$ ditahun 2011, sementara tahun 2012 walaupun dilihat dari jumlah mengalami kenaikan, tapi trend-nya kembali mengalami penurunan menjadi 14\%. Masalah ini merupakan masalah klasik dalam dunia perbankan syariah, SDM yang ada masih belum memenuhi kebutuhan, oleh karena itu penyelesaiannya harus dilakukan bersama-sama baik sokongan dari pemerintah, pelaku industri perbankan itu sendiri, masyarakat, maupun industri pendidikan yang sampai saat ini dirasa menjadi tempat yang tepat untuk menciptakan SDM yang berkompeten.

Lebih khusus bagi institusi keuangan syariah, jenjang pendidikan yang disiapkan untuk memenuhi kebutuhan SDM bagi perbankan dan lembaga keuangan syariah adalah sekolah tinggi yang memang fokus pada pendidikan ilmu Ekonomi Islam, lembaga pendidikan tersebut sudah mulai bermunculan, dapat dilihat dari tabel berikut. 
Tabel 0.3

Jumlah Perguruan Tinggi Ekonomi Islam di Pulau Jawa dan Sumatera

\begin{tabular}{|l|c|c|}
\hline \multicolumn{1}{|c|}{ Kelompok Perguruan Tinggi } & 1997-1999 & 2000-sekarang \\
\hline Perguruan Tinggi Negeri (PTN) & - & 5 \\
\hline Perguruan Tinggi Swasta (PTS) & - & 10 \\
\hline $\begin{array}{l}\text { Perguruan Tinggi Agama Islam (PTAI) } \\
\text { Negeri }\end{array}$ & 2 & $8^{*}$ \\
\hline $\begin{array}{l}\text { Perguruan Tinggi Agama Islam (PTAI) } \\
\text { Swasta }\end{array}$ & 4 & $7^{*}$ \\
\hline \multicolumn{1}{|c|}{ TOTAL } & 6 & 30 \\
\hline
\end{tabular}

*jumlah sudah termasuk pada periode tahun sebelumnya, Sumber: Diolah dari berbagai sumber

Tabel di atas membuktikan bahwa sudah terdapat cukup banyak lembaga pendidikan khususnya perguruan tinggi yang konsen menciptakan SDM bagi industri perbankan dan lembaga keuangan syariah. Daerah Jawa dan Sumatera dinilai sebagai daerah yang cukup pesat mengalami perkembangan dalam dunia ekonomi Islam. Perkembangan yang terjadi pun cukup signifikan, dari total perguruan tinggi secara umum pada tahun 1997-1999 baru terdapat 6 perguruan tinggi yang menyelenggarakan studi ekonomi Islam, kemudian menjadi 30 perguruan tinggi setelah melewati era milenium ditahun 2000 sampai dengan sekarang. Sehingga jika dihitung secara rata-rata muncul dua perguruan tinggi ekonomi Islam setiap tahunnya dalam kurun waktu 16 tahun terakhir.

Jumlah tersebut tentu belum mencukupi kebutuhan SDM perbankan dan lembaga keuangan syariah. Standardisasi yang dicanangkan perbankan syariah untuk SDM jangka panjang yang berarti SDM yang dapat dipekerjakan di perbankan adalah SDM lulusan setara Strata 1 (S1), memunculkan semacam perebutan SDM lulusan sekolah tinggi syariah yang jumlahnya masih jauh dari kebutuhan SDM industri Perbankan Syariah di Indonesia. Maka, untuk memenuhi kebutuhan tersebut, pihak Perbankan Syariah masih menerima lulusan S1 dari jurusan selain syariah, namun tetap dengan seleksi yang telah terstandardisasi.

Salah satu sekolah tinggi yang konsen dalam bidang pengembangan Ekonomi Islam adalah Sekolah Tinggi Ekonomi Islam (STEI) SEBI. Sejak berdiri tahun 1998 dan dalam kurun waktu beberapa tahun terakhir STEI SEBI mengalami cukup banyak perubahan, mulai dari lokasi yang berubah sejak tahun 2010 di Jl. Raya Bojongsari, Sawangan, Depok setelah sebelumnya sejak awal berdiri tahun 1998 pernah berlokasi di J1. Margonda, Depok selama beberapa tahun dan kemudian pindah ke Jl. Ir. H. Djuanda, Ciputat. STEI SEBI memiliki visi "Terdepan dalam Pengembangan Ekonomi dan Lembaga Keuangan Syariah"(Sekolah Tinggi Ekonomi Islam SEBI, 2013), menjadikannya terus menerus meningkatkan kualitas SDM yang dikelola, dalam hal ini mahasiswa. Perkembangan jumlah mahasiswa dapat kita lihat dalam grafik berikut. 
Grafik 2.1

Perkembangan Jumlah Mahasiswa STEI SEBI Pertahun/Angkatan (")

\section{Sumber : Akademik SEBI 2012}

Grafik tersebut memperlihatkan pertumbuhan, seperti pada tahun 2008 ke 2009 mengalami trend kenaikan sebesar 7\%, begitu pula tahun 2009 ke tahun 2010 juga mengalami kenaikan 7\%, ada hal yang menarik, yaitu kenaikan trend pada tahun 2010 ke tahun 2011 sebesar 60\%, kenaikan tersebut cukup signifikan, hal itu terjadi salah satunya setelah STEI SEBI berlokasi di kampus baru Sawangan, Depok. Tapi trend kenaikan pada tahun 2011 ke tahun 2012 belum terlalu signifikan yakni hanya sebesar 12\%, artinya setiap tahun STEI SEBI mampu meningkatkan jumlah mahasiswa. Jumlah total mahasiswa aktif sampai tahun ajaran semester ganjil 2012/2013 yakni mencapai 648 mahasiswa dengan jumlah 251 mahasiswa jurusan Akuntansi Syariah (AS) dan 397 mahasiswa jurusan Perbankan Syariah.

Namun, jika kita bandingkan dengan kebutuhan akan jumlah SDM Perbankan Syariah secara keseluruhan, angka tersebut dirasa masih sangat jauh dari cukup. Ditambah perguruan tinggi yang konsen dalam pengembangan Ekonomi Islam belum semenjamur perguruan tinggi dengan jurusan umum. Atas dasar itulah penulis ingin mengetahui lebih dalam tentang minat mahasiswa STEI SEBI dalam memilih Perguruan Tinggi Swasta, serta peluangnya dalam menciptakan SDM melalui institusi pendidikan sekolah tinggi Ekonomi Islam, maka penulis mengambil judul "Faktor yang Mempengaruhi Minat Mahasiswa Memilih Perguruan Tinggi Ekonomi Islam (Studi Empiris STEI SEBI, Depok)".

\section{Rumusan Masalah}

Kebutuhan SDM keuangan syariah yang berkompeten masih menjadi masalah klasik yang membutuhkan kerjasama dari semua pihak baik dari pemerintah, pelaku industri keuangan itu sendiri, pelaku industri pendidikan dan masyarakat. Peran perguruan tinggi khususnya yang 
konsen dalam bidang ilmu syariah dalam memenuhi kebutuhan SDM tersebut harus dimaksimalkan, mengingat masih sedikitnya jumlah perguruan tinggi syariah yang konsen dalam bidang Ekonomi Islam. Maka faktor minat dari mahasiswa itu sendiri dalam memilih perguruan tinggi turut mempengaruhi jumlah SDM, sehingga diperlukan penelitian lebih dalam tentang faktor tersebut yang dituang dalam rumusan masalah berikut:

a. Bagaimana karakteristik mahasiswa di perguruan tinggi Ekonomi Islam?

b. Faktor apa sajakah yang paling mempengaruhi minat mahasiswa terhadap perguruan tinggi Ekonomi Islam?

\section{BAB II LANDASAN TEORI}

\section{1. Teori Minat}

Pengertian minat dalam Kamus Besar Bahasa Indonesia adalah "kecenderungan hati yang tinggi terhadap sesuatu, gairah, ataupun keinginan,"(Nasional, 2007, hal. 744). Sedangkan menurut Agus Sujanto (2004), dalam bukunya Psikologi Umum, "minat sama dengan kemauan, yaitu kekuatan yang sadar dan hidup, atau menciptakan sesuatu berdasarkan perasaan dan pikiran," (hal. 86). Menurut Rahman Shaleh, dkk (2004, hal. 263), "secara sederhana minat dapat diartikan sebagai suatu kecenderungan untuk memberikan perhatian dan bertindak terhadap orang, aktivitas atau situasi yang menjadi objek dari minat tersebut dengan disertai perasaan senang."

Hurlock (1999) juga menyatakan bahwa,

"Minat yang merupakan kecenderungan secara sadar seseorang tidak muncul begitu saja, minat terbentuk melalui pertumbuhan, kematangan berpikir, proses belajar dan pengalaman. Minat dapat berubah sesuai dengan fase perkembangan dan pertumbuhan seseorang. Semakin dewasa seseorang maka semakin stabil kondisi minat dalam dirinya baik secara kuantitatif maupun kualitatif(hal. 270).

Masih menurut Abdul Rahman Shaleh dan Muhbib Abdul Wahab (2004, hal. 264-265), ada tiga faktor yang menjadi timbulnya minat, yaitu :

\section{Faktor dari dalam diri individu}

Misalnya dorongan untuk makan, ingin tahu sesuatu. Dorongan untuk makan akan membangkitkan minat untuk bekerja atau mencapai penghasilan, minat terhadap produksi makanan, dan lain-lain. Dorongan ingin tahu atau rasa ingin tahu akan membangkitkan minat untuk membaca, belajar, menuntut ilmu, melakukan penelitian dan lain-lain. 


\section{Motif sosial}

Dapat menjadi faktor yang membangkitkan minat untuk melakukan suatu aktivitas. Misalnya minat terhadap pakaian timbul karena ingin mendapat persetujuan atau penerimaan dan perhatian dari orang lain. Minat untuk belajar timbul karena ingin mendapat penghargaan dari masyarakat.

\section{Faktor emosional}

Minat mempunyai hubungan yang erat dengan emosi. Bila seseorang mendapat kesuksesan pada aktivitas yang dilakukannya, maka akan timbul rasa senang dan hal tersebut akan memperkuat rasa minat terhadap aktivitas tersebut, sebaliknya suatu kegagalan akan menghilangkan minat terhadap hal tersebut.

Sedangkan beberapa kondisi yang mempengaruhi minat individu sebagai berikut (Sunarto, 2002, hal. 167-168):

\section{a. Faktor sosial-ekonomi}

Kondisi sosial-ekonomi keluarga banyak menentukan kehidupan pendidikan dan karir anak. Kondisi sosial yang menggambarkan status orang tua yang merupakan faktor yang akan 'dilihat' oleh anak untuk menentukan pilihan sekolah dan pekerjaan. Secara tidak langsung keberhasilan orang tuanya merupakan 'beban' bagi anak, sehingga dalam menentukan pilihan pendidikan tersirat untuk ikut mempertahankan kedudukan orang tuanya.

\section{b. Tempat tinggal}

Tempat di mana seseorang tinggal yang banyak dipengaruhi oleh keinginan yang biasa mereka penuhi dalam kehidupan sebelumnya, apakah kebiasaan tersebut masih dapat dilakukan atau tidak

\section{c. Faktor lingkungan}

Lingkungan yang dimaksud disini meliputi tiga macam.

Pertama, lingkungan kehidupan masyarakat seperti lingkungan masyarakat perindustrian, pertanian, perdagangan, maupun lingkungan yang masyarakatnya rata-rata terdidik. Lingkungan semacam itu akan memebentuk sikap anak dalam menentukan pola kehidupan yang pada akhirnya akan memepengaruhi pemikirannya dalam menentukan jenis pendidikan dan pekerjaan yang diidamkannya.

Kedua, lingkungan kehidupan rumah tangga dan kondisi sekolah. Lembaga pendidikan atau sekolah yang baik mutunya, memiliki disiplin tinggi, akan sangat berpengaruh terhadap pembentukkan 
sikap dan perilaku kehidupan pendidikan anak dan pola pikir karirnya.

Ketiga, lingkungan kehidupan teman sebaya, meliputi pergaulan sehari-hari dengan teman sebaya akan memeberikan pengaruh terhadap kehidupan pendidikan masing-masing remaja.

\section{2. Pengertian Pemasaran}

Pemasaran merupakan terjemahan yang berasal dari bahasa Inggris yaitu marketing, yang mempunyai pengertian sangat luas sesuai dengan perkembangan ekonomi dan teknologi. Definisi pemasaran menurut Kotler (Kotler, 2002, hal. 17) adalah "Proses sosial dan manajerial dimana individu dan kelompok mendapatkan kebutuhan dan keinginan mereka dengan menciptakan, menawarkan dan bertukar sesuatu yang bernilai satu sama lain.”

Definisi pemasaran ini bersandar pada konsep inti: kebutuhan (needs), keinginan (wants), dan permintaan (demands); produk (barang, jasa, dangagasan); nilai, biaya, dan kepuasan; pertukaran, transaksi dan hubungan; pasardan pemasaran serta pemasar.

\section{3. Pengertian Jasa}

Kotler dan Keller (2006) mengemukakan pengertian jasa (service) sebagai berikut, "A service is any act or performance that one party can offer to another that is essentially intangible and does bot result in the ownership of anything. Its production may or may not be tied to a physical product." (Jasa adalah setiap tindakan atau kinerja yang ditawarkan oleh satu pihak ke pihak lain yang secara prinsip tidak berwujud dan tidak menyebabkan perpindahan kepemilikan. Produksi jasa tidak dapat terikat pada suatu produk fisik).

Jasa pada dasarnya adalah seluruh aktifitas ekonomi dengan output selain produk dalam pengertian fisik, dikonsumsi dan diproduksi pada saat bersamaan, memberi nilai tambah dan secara prinsip tidak berwujud bagi pembeli pertamanya. Berdasarkan beberapa definisi yang telah dijelaskan di atas, maka jasa mempunyai ciri-ciri sebagai berikut:

- Suatu yang tidak berwujud, tetapi dapat memenuhi kebutuhan konsumen.

- Proses produksi jasa dapat menggunakan atau tidak menggunakan bantuan suatu produk fisik.

- Jasa tidak mengakibatkan peralihan hak atau kepemilikan.

- Terdapat interaksi antara penyedia jasa dengan pengguna jasa. 


\section{4.Perilaku Konsumen}

\subsubsection{Definisi Perilaku Konsumen}

Hawkins, Best \& Coney (2001, p. 4) menyatakan bahwa "perilaku konsumen adalah studi mengenai individu, kelompok atau organisasi dan proses-prosesyang dilakukan dalam memilih, menentukan, mendapatkan, menggunakan, danmenghentikan pemakaian produk, jasa, pengalaman, atau ide untuk memuaskankebutuhan serta dampak proses-proses tersebut terhadap konsumen dan masyarakat." Sedangkan menurut Gerald Zaldman dalam Dwiastuti(2012, p. 3) perilaku konsumen adalah"tindakan-tindakan, proses dan hubungan social yang dilakukan individu, kelompok dan organisasi dalam mendapatkan, menggunakan suatu produk atau lainnya sebagai suatu akibat dari pengalamannya dengan produk, pelayanan dan sumber-sumber lainnya."Adapun definisi lainnya mengungkapkan bahwa perilaku konsumen adalah "perilaku yang diperlihatkan konsumen dalam mencari, membeli, menggunakan, mengevaluasi dan menghabiskan produk dan jasa yang mereka harapkan akan memuaskan kebutuhan mereka" (Dwiastuti, 2012, p. 7)

\subsubsection{Faktor yang Mempengaruhi Perilaku Beli Konsumen}

Terdapat beberapa faktor yang mempengaruhi keputusan konsumen dalam memutuskan untuk membeli suatu produk barang/jasa, seperti dijelaskan sebagai berikut (Ali Hasan, 2002, hal. 131-137).

\section{a. Budaya (Cultural)}

Merupakan sekumpulan nilai, persepsi, preferensi dan perilaku tertentu yang diperoleh dari lingkungan keluarga, agama, bangsa, ras, dan geografis. Dampaknya, produsen dapat membuat banyak segmen pasar yang disesuaikan dengan kebutuhan segmen.

b. Kelas Sosial (Social Class)

Secara formal atau tidak, masyarakat memiliki stratifikasi/kelas sosial tertentu, yakni pembagian kelompok masyarakat yang relatif homogen dan permanen yang tersusun secara sistematis, anggotanya menganut nilai, minat dan perilaku yang serupa. Marketer dapat membuat suatu produk yang sesuai dengan kelas sosial mereka.

\section{c. Kelompok Acuan (Refference Groups)}

Seseorang dalam kelompok tertentu yang memiliki pengaruhpengaruh langsung terhadap sikap dan perilakunya (keanggotaan kelompok). Dalam hal ini produsen dapat mengidentifikasi kelompok acuan yang mempunyai pengaruh yang kuat terhadap produk/merek.

d. Keluarga (Family) 
Keluarga merupakan organisasi kecil yang penting dalam mempengaruhi perilaku anggotanya yang bersumber dari orangtua. Produsen perlu mengidentifikasi peran yang relatif dominan antara suami/istri/anak dalam keluarga yang berpengaruh dalam membeli produk barang/jasa.

\section{e. Motivasi}

Merupakan dorongan kebutuhan yang membentuk perilaku yang bersifat biologis (lapar, haus, tidak nyaman) dan psikologis (pengakuan, penghargaan, atau keanggotaan kelompok) serta aktualisasi optimal.

\section{f. Pribadi (Personal)}

Karakter pribadi menjadi faktor penentu dalam pembelian. Sejumlah karakteristik pribadi seperti usia, tahap siklus hidup, pekerjaan dan kemampuan ekonomi mempengaruhi produk atau merek yang dibeli. Dampaknya produsen harus memilih kelompok pasar berdasarkan usia dan tahap siklus hidup, pekerjaan dan kemampuan ekonomi (terutama harga) sebagai target pasarnya.

\section{g. Kepribadian (Personality)}

Kepribadian merupakan karakteristik psikologis yang berbeda pada masing-masing orang yang menyebabkan tanggapannya relatif konsisten dan bertahan lamaterhadap pilihan produk atau merek. Kepribadian ini mencakup kepercayaan diri, dominasi, otonomi, kehormatan, kemampuan bersosialisasi, pertahanan diri, dan kemampuan beradaptasi.

\section{h. Citra Diri (Self Image)}

Citra atau konsep tentang diri yang ideal dan aktual seseorang. Marketer harus berusaha mengembangkan citra merek yang sesuai citra pribadi target pasar.

i. Gaya Hidup (Life Style)

Keseluruhan pola hidup seseorang yang diekspresikan dalam aktivitas, minat dan opini yang berinteraksi dengan lingkungannya. Sehingga produsen harus mampu menemukan korelasi antara produk dengan gaya hidup konsumen yang menjadi target pasarnya.

j. Pembelajaran

Perubahan perilaku seseorang yang dibentuk oleh pengalaman yang didorong secara internal, dituntun oleh petunjuk, sehingga menyebabkan timbulnya generalisasi dan diskriminasi. Marketer perlu membangun permintaan produk yang menimbulkan 
dorongan, melalui generalisasi (kemiripan) dan diskriminasi (perpindahan merek-produk).

k. Sikap

Sikap yang kita yakini, rasakan dan ingin dilakukan berhubungan dengan stimuli pemasaran atau lingkungan yang kita hadapi.

\section{5. Pendidikan}

\subsubsection{Definisi Pendidikan}

Pendidikan berasal dari kata didik, lalu kata ini mendapat awalan sehingga menjadi mendidik, artinya memelihara dan memberi latihan. Dalam memelihara dan memberi latihan diperlukan adanya ajaran, tuntutan, dan pimpinan mengenai akhlak dan kecerdasan pikiran. Selanjutnya, pengertian pendidikan menurut Kamus Besar Bahasa Indonesia ialah proses pengubahan sikap dan tata laku seseorang atau kelompok orang dalam usaha mendewasakan manusia melalui upaya pengajaran dan pelatihan. (Pusat Bahasa Indonesia, 2008).

Definisi lain tentang pendidikan adalah salah satu proses pembaharuan makna pengalaman. Hal ini mungkin akan terjadi di dalam pergaulan biasa atau pergaulan orang dewasa dengan orang muda. Bahkan, mungkin pula terjadi secara sengaja dan dilembagakan untuk menghasilkan kesinambungan sosial. Proses ini melibatkan pengawasan dan perkembangan dari orang yang belum dewasa dan kelompok tempat dia hidup (Dewey, 1998).

\subsubsection{Tujuan Pendidikan}

Menurut UU. No.2 Tahun 1985 yaitu mencerdaskan kehidupan bangsa dan mengembangkan manusia yang seutuhnya yaitu yang beriman dan dan bertagwa kepada tuhan yang maha esa dan berbudi pekerti luhur, memiliki pengetahuan dan keterampilan, kesehatan jasmani dan rohani, kepribadian yang mantap dan mandiri serta rasa tanggung jawab kemasyarakatan dan berbangsa.

\section{6. Penelitian Terdahulu}

Berikut penelitian yang penulis temukan terkait dengan penelitian ini, dapat dilihat dalam tebel di bawah ini. 


\begin{tabular}{|c|c|c|c|c|}
\hline No. & $\begin{array}{c}\text { Tahun/ } \\
\text { Asal } \\
\text { Daerah/ } \\
\text { Institusi }\end{array}$ & Judul & $\begin{array}{c}\text { Nama } \\
\text { Penulis }\end{array}$ & Pembahasan \\
\hline 1 & $\begin{array}{l}\text { 2012/ } \\
\text { Depok/ } \\
\text { STEI SEBI }\end{array}$ & $\begin{array}{l}\text { MENENTUK } \\
\text { AN } \\
\text { FAKTOR- } \\
\text { FAKTOR } \\
\text { YANG } \\
\text { MEMILIKI } \\
\text { HUBUNGAN } \\
\text { MINAT } \\
\text { MAHASISW } \\
\text { A STEI SEBI } \\
\text { MENABUN } \\
\text { G DI SEBI } \\
\text { ISLAMIC } \\
\text { BANK }\end{array}$ & $\begin{array}{l}\text { Hendi } \\
\text { Mulyan } \\
\text { a }\end{array}$ & $\begin{array}{l}\text { Alat Analisis:CHAID-Chi Square. } \\
\text { Hasil Analisis :Hasil darianalisis Chi-Square } \\
\text { menyimpulkan, dari } 31 \text { indikator ada } 6 \\
\text { indikator yang memiliki keterkaitan dengan } \\
\text { minat mahasiswa menabung di SIB yaitu, } \\
\text { tempat tinggal dekat dengan kampus, pengaruh } \\
\text { lingkungan tempat tinggal, produk tabungan } \\
\text { yang unik dan tidak unik, sistem bagi hasil non } \\
\text { riba, pengaruh uang saku, dan pengaruh } \\
\text { banyaknya teman yang menabung. Dimana } \\
\text { masing-masing indicator menghasilkan X2 } \\
\text { hitung di atas } 7,290 \text { sampai dengan } 18,739 \text {. }\end{array}$ \\
\hline 2 & $\begin{array}{l}\text { 2012/ } \\
\text { Jakarta/ } \\
\text { Universitas } \\
\text { Islam Al- } \\
\text { Azhar }\end{array}$ & 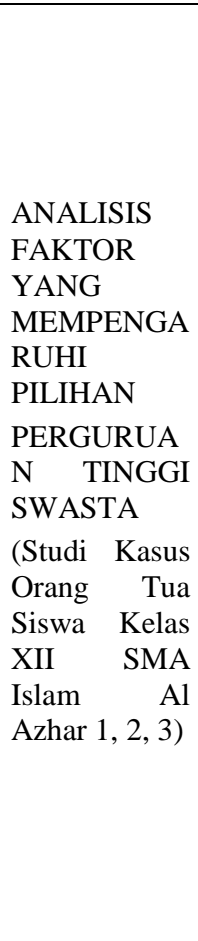 & $\begin{array}{l}\text { Lulu } \\
\text { Wulanja } \\
\text { nu }\end{array}$ & $\begin{array}{l}\text { Alat Analisis :Deskriptif kuantitatif dan } \\
\text { Analisis Faktor, dimana deskriptif kuantitatif } \\
\text { digunakan untuk mengetahui karakteristik dari } \\
\text { konsumen yaitu orang tua siswa. Kemudian } \\
\text { menggunakan analisis faktor untuk melihat } \\
\text { faktor apa saja yang mempengaruhi orang tua } \\
\text { dalam memilih PTS. } \\
\text { Hasil Analisis : Responden dari penelitian ini } \\
\text { adalah orangtua siswa kelas XII SMA Al } \\
\text { Azhar 1, 2, dan } 3 \text { Jakarta. Dari penelitian ini } \\
\text { didapat kesimpulan bahwa PTS harus dapat } \\
\text { memaksimalkan potensi yang ada di dalam } \\
\text { lembaga mereka agar dapat bersaing dengan } \\
\text { Perguruan Tinggi Swasta lain atau bahkan } \\
\text { Perguruan Tinggi Negeri. Secara keseluruhan } \\
\text { unsur-unsur tersebut harus } \\
\text { dimaksimalkan agar dapat memenuhi } \\
\text { kebutuhan calon konsumen. Adapun unsur } \\
\text { tersebut ada enam, yaitu: atribut produk, } \\
\text { manfaat, nilai, budaya, kepribadian, dan } \\
\text { pemakai. Kemudian didapatkan } 14 \text { faktor yang } \\
\text { mempengaruhi pilihan tersebut, yaitu : status } \\
\text { akreditasi, biaya perkuliahan, fasilitas kampus, } \\
\text { lokasi strategis, iklan yang menarik, pilihan } \\
\text { jurusan, pilihan kegiatan mahasiswa, kualitas } \\
\text { pengajar, mudahnya lulusan diterima di dunia } \\
\text { kerja, kualitas alumni, citra (image) perguruan } \\
\text { tinggi, lingkungan sosial perguruan tinggi, } \\
\text { nilai-nilai agama, proses akademis. }\end{array}$ \\
\hline 3 & $\begin{array}{l}\text { 2006/ } \\
\text { Jakarta/ } \\
\text { Sekolah } \\
\text { Tinggi } \\
\text { Ilmu } \\
\text { Statistik }\end{array}$ & $\begin{array}{l}\text { FAKTOR- } \\
\text { FAKTOR } \\
\text { DOMINAN } \\
\text { DALAM } \\
\text { PENGEMBA } \\
\text { NGAN } \\
\text { PRODUKSI } \\
\end{array}$ & $\begin{array}{l}\text { Abdul } \\
\text { Murat } \\
\text { Musyafi } \\
\mathrm{r}\end{array}$ & $\begin{array}{l}\text { Alat Analisis :Analisis deskriptif kuantitatif, } \\
\text { analisis faktor, regresi linear. } \\
\text { Hasil Analisis :Berdasarkan hasil analisis } \\
\text { komponen utama dan analisis faktor terhadap } \\
14 \text { variabel yang diharapkan memiliki } \\
\text { pengaruh terhadap produksi padi terdiri dari } \\
\text { tiga komponen utama. Pertama, berupa } \\
\text { kumpulan faktor peubah sawah bririgasi }\end{array}$ \\
\hline
\end{tabular}




\begin{tabular}{|c|c|c|c|c|}
\hline & & $\begin{array}{l}\text { TANAMAN } \\
\text { PADI DI } \\
\text { SULAWESI } \\
\text { SELATAN }\end{array}$ & & $\begin{array}{l}\text { setengah teknis, irigasi sederhana, luas lahan } \\
\text { dikonversi, jumlah rumah tangga petani padi, } \\
\text { jumlah penduduk, jumlah alat dan mesin } \\
\text { pertanian, luas lahan kering yang sementara } \\
\text { tidak diusahakan, dan luas ladang. Komponen } \\
\text { kedua terdiri dari peubah luas sawah beririgasi } \\
\text { teknis, rata-rata pendapatan rumah tangga dari } \\
\text { sektor tanaman padi, dan rata-rata biaya } \\
\text { produksi. Komponen ketiga disusun oleh } \\
\text { peubah luas sawah tadah hujan, luas lahan } \\
\text { yang ditanami padi, dan luas panen padi. }\end{array}$ \\
\hline 4 & $\begin{array}{l}\text { 2006/ } \\
\text { Bogor/ } \\
\text { Institut } \\
\text { Pertanian } \\
\text { Bogor } \\
\text { (IPB) }\end{array}$ & $\begin{array}{l}\text { ANALISIS } \\
\text { PERILAKU } \\
\text { KONSUMEN } \\
\text { DALAM } \\
\text { PROSES } \\
\text { KEPUTUSA } \\
\mathrm{N} \\
\text { PEMBELIAN } \\
\text { BUKU } \\
\text { BERTEMAK } \\
\text { AN ISLAM }\end{array}$ & $\begin{array}{l}\text { Kusuma } \\
\text { ningrum } \\
\text { Fatimah }\end{array}$ & $\begin{array}{l}\text { Alat Analisis : Chi-Square } \\
\text { Hasil Analisis : Terdapat empat faktor utama } \\
\text { yang mempengaruhi keputusan pembelian } \\
\text { buku, yaitu faktor eksternal, atribut produk, } \\
\text { keuangan konsumen, dan internal, dimana } \\
\text { masing-masing faktor menghasilkan nilai } \mathrm{X}^{2} \\
\text { hitung di atas } 0,550 \text { sampai dengan } 0,796 .\end{array}$ \\
\hline
\end{tabular}

\subsection{Kerangka Hipotesis}

Hipotesis merupakan jawaban sementara terhadap rumusan masalah penelitian, dimana rumusan masalah penelitian telah dinyatakan dalam bentuk kalimat pernyataan. Hipotesis yang digunakan dalam penelitian ini adalah hipotesisi asosiatif, yakni jawaban sementara terhadap rumusan masalah yang menanyakan hubungan antara dua variabel atau lebih. (Sugiyono, 2011, hal. 69)

Dalam penelitian ini, faktor-faktor yang ditetapkan adalah gabungan dari faktor-faktor yang didapatkan dari studi pustaka dan penelitian terdahulu yang telah dijelaskan sebelumnya. Faktor-faktor tersebut digabungkan untuk kemudian ditentukan beberapa indikator untuk dijadikan faktor peubah agar faktor tersebut dapat dianalisis, sehingga hipotesisnya sebagai berikut,

a. H1 : Adanya hubungan antara variabelindividuterhadapminat mahasiswa memilih perguruan tinggi Ekonomi Islam.

b. H2 : Adanya hubungan antara variabel sosial-ekonomi terhadapminat mahasiswa memilih perguruan tinggi Ekonomi Islam.

c. H3 : Adanya hubungan antara variabel Lingkungan terhadapminat mahasiswa memilih perguruan tinggi Ekonomi Islam.

d. H4 : Adanya hubungan antara variabel citra/image terhadapminat mahasiswa memilih perguruan tinggi Ekonomi Islam. 


\section{BAB III METODOLOGI PENELITIAN}

\section{1. Jenis Penelitian}

Jenis penelitian yang penulis gunakan adalah kuantitatif. Penelitian kuantitatif dapat diartikan sebagai metode penelitian yang berlandaskan pada filsafat positivisme, digunakan untuk meneliti pada populasi atau sampel tertentu, teknik pengambilan sampel pada umumnya dilakukan secara random, pengumpulan data menggunakan instrumen penelitian, analisis data bersifat kuantitatif/statistik dengan tujuan untuk menguji hipotesis yang telah ditetapkan (Sugiyono, 2011, hal. 8).

Penelitian ini membahas tentang faktor-faktor yang mempengaruhi minat mahasiswa terhadap perguruan tinggi jurusan Ekonomi Islam. Variabel mandiri dalam penelitian ini yaitu faktor-faktor yang mempengaruhi mahasiswa memilih perguruan tinggi Ekonomi Islam khususnya di STEI SEBI.

\section{2. Jenis dan Teknik Pengumpulan Data}

Teknik pengumpulan data dalam penelitian ini yaitu:

\subsubsection{Data Primer}

Data primer adalah data yang dihimpun langsung oleh peneliti (Riduwan, 2007, hal. 24). Data langsung yang penulis kumpulkan adalah sebagai berikut.

\section{a. Observasi Langsung}

Dilakukan dengan mencari data langsung pada objek penelitian, seperti data mengenai lama berdirinya perguruan tinggi, dan jumlah mahasiswa per-angkatan.

\section{b. Kuesioner}

Pengambilan data melalui kuesioner dilakukan dengan memberi sejumlah pertanyaan maupun pernyataan tertulis kepada responden yang terdiri dari mahasiswa STEI SEBI angkatan 2011 dan 2012 jurusan Perbankan dan Akuntansi Syariah.

\subsubsection{Data Sekunder}

Data sekunder merupakan data yang dihimpun melalui tangan kedua (Riduwan, 2007, hal. 24). Data sekunder peneliti dapatkan melalui cara berikut.

\section{a. Studi Pustaka}

Data yang diperoleh melalui dasar-dasar teori yang terkait dengan pembahasan mengenai minat, teori pemasaran, perilaku konsumen, 
dan pengertian pendidikan yang didapat dari buku, jurnal, artikel, majalah, media internet maupun media lainnya.

\section{b. Dokumentasi}

Data yang didapat langsung dari tempat yang menjadi objek penelitian, seperti jurnal kampus, data akademik, dan website resmi kampus.

\section{3. Populasi dan Sampel}

\subsubsection{Populasi}

Populasi dalam penelitian ini merupakan mahasiswa STEI SEBI angkatan 2011 dan 2012, hal tersebut dikarenakan peneliti menemukan trend kenaikan jumlah mahasiswa yang signifikan bertambah sebesar 60\%, serta mahasiswa angkatan 2011 dan 2012 mengawali aktivitas perkuliahan di gedung kampus baru STEI SEBI Depok, dengan jumlah total sebagai berikut:

Tabel 0.1

Jumlah Mahasiswa STEI SEBI Angkatan 2011 dan 2012

\begin{tabular}{|c|c|c|c|}
\hline \multirow{2}{*}{$\mathbf{1}$} & Angkatan & Program Studi & $\begin{array}{c}\text { Jumlah } \\
\text { Mahasiswa }\end{array}$ \\
\hline \multirow{2}{*}{2011} & $\begin{array}{c}\text { Akuntansi } \\
\text { Syariah }\end{array}$ & 52 \\
\cline { 3 - 4 } & \multirow{2}{*}{2} & $\begin{array}{c}\text { Perbankan } \\
\text { Syariah }\end{array}$ & 143 \\
\hline \multirow{2}{*}{2012} & $\begin{array}{c}\text { Akuntansi } \\
\text { Syariah }\end{array}$ & 89 \\
\cline { 3 - 4 } & & $\begin{array}{c}\text { Perbankan } \\
\text { Syariah }\end{array}$ & 129 \\
\hline
\end{tabular}

Sumber: Data Akademik SEBI, 2013

Jumlah Populasi penelitian ini 413 mahasiswa aktif pada semester genap tahun ajaran 2012/2013 yang berasal dari jurusan Akuntansi dan Perbankan Syariah angkatan 2011 dan 2012.

\subsubsection{Sampel}

Sampel merupakan bagian dari populasi yang ingin diteliti (Bambang Prasetyo, 2007, hal. 119). Untuk menentukan ukuran sampel dalam penelitian ini, penulis menggunakan rumus slovin seperti berikut:

$$
\mathrm{n}=\frac{\mathrm{N}}{1+N \cdot e^{2}}
$$

Dimana :

$\mathrm{n} \quad=$ ukuran sampel

$\mathrm{N} \quad=$ ukuran populasi 
e $=$ persen kelonggaran ketidak telitian karena kesalahan pengambilan sampel yang masih dapat ditolerir, misalnya $10 \%$.

Teknik sampling yang digunakan dalam penelitian ini adalah teknik probability sampling, yaitu teknik pengambilan sampel yang memberikan peluang yang sama bagi setiap unsur (anggota) populasi untuk dipilih menjadi anggota sampel. Probability sampling yang penulis gunakan adalah teknik proportionate stratified randomsampling, yakni pengambilan sampel yang digunakan bila populasi mempunyai anggota/unsur yang tidak homogen dan berstrata secara proporsional (Sugiyono, 2011, hal. 82). Adapun sampel yang penulis teliti adalah mahasiswa STEI SEBI jurusan Akuntansi dan Perbankan Syariah yang berasal dari angkatan 2011 dan 2012.

Jika diketahui jumlah populasi $(\mathrm{N})=413$, toleransi ketidak telitian (e) $=10 \%$, maka sampel sebagai berikut.

$$
\begin{aligned}
& \mathrm{n}=\frac{413}{1+413(0,1)^{2}} \\
& \mathrm{n}=\frac{413}{5,13} \\
& \mathrm{n}=80,51
\end{aligned}
$$

\section{Maka, jumlah sampel yang diambil dibulatkan menjadi 81 responden}

Dengan demikian, berdasarkan rumus proportionate stratified randomsampling yaitu (Bambang Prasetyo, 2007, hal. 130).

$$
\mathrm{n} i=\frac{\mathrm{N} i \cdot \mathrm{n}}{\mathrm{N}}
$$

Keterangan:

$\mathrm{n} i \quad=$ Jumlah sampel menurut strata

$\mathrm{N} i=$ Jumlah populasi menurut strata

$\mathrm{n} \quad=$ Jumlah sampel seluruhnya

$\mathrm{N} \quad=$ Jumlah populasi seluruhnya

Maka, besarnya sampel per-angkatan sesuai jurusan mahasiswa sebagai berikut. 
Tabel 0.2

Jumlah Sampel Penelitian Berdasarkan Strata

\begin{tabular}{|c|c|c|l|}
\hline No. & Angkatan & Program Studi & \multicolumn{1}{c|}{$\begin{array}{c}\text { Jumlah } \\
\text { Mahasiswa }\end{array}$} \\
\hline \multirow{2}{*}{1} & \multirow{2}{*}{2011} & $\begin{array}{c}\text { Akuntansi } \\
\text { Syariah }\end{array}$ & $=\frac{\mathbf{5 2 . 8 1}}{413}=10$ \\
\cline { 3 - 4 } & & $\begin{array}{c}\text { Perbankan } \\
\text { Syariah }\end{array}$ & $=\frac{143.81}{413}=28$ \\
\hline \multirow{2}{*}{2} & \multirow{2}{*}{2012} & $\begin{array}{c}\text { Akuntansi } \\
\text { Syariah }\end{array}$ & $=\frac{89.81}{413}=17,46 \rightarrow$ \\
\cline { 3 - 4 } & & $\begin{array}{c}\text { Perbankan } \\
\text { Syariah }\end{array}$ & $=\frac{18.81}{413}=25$ \\
\hline & \multicolumn{2}{|c|}{ JUMLAH } & 81 \\
\hline
\end{tabular}

Sumber: Data primer yang diolah

Dari tabel tersebut didapatkan sampel penelitian berdasarkan strata dari Angkatan 2011 jurusan Akuntansi sebanyak 10 mahasiswa, dan jurusan Perbankan Syariah sebanyak 28 mahasiswa. Sedangkan angkatan 2012 jurusan Akuntansi Syariah sebanyak 17,46 yang dibulatkan menjadi 18 mahasiswa, dan jurusan Perbankan Syariah sebanyak 25 mahasiswa. Sehingga total sampel sesuai dengan Rumus Slovin yakni 81 responden.

\section{4. Instrumen Penelitian}

Arikunto dalam Riduwan (2007, hal. 32) mengatakan bahwa "Instrumen penelitian merupakan yang terpenting dan strategis kedudukannya di dalam keseluruhan kegiatan penelitian". Maka, peneliti menyusun instrumen penelitian berikut berdsarkan landasan teori dan penelitian sebelumnya yang telah dijelaskan sebelumnya, sehingga didapatkan sebagai berikut.

Tabel 0.3

Instrumen Penelitian

\begin{tabular}{|c|c|c|c|}
\hline $\begin{array}{l}\text { Variabel } \\
\text { Mandiri }\end{array}$ & $\begin{array}{l}\text { Variabel } \\
\text { Turunan }\end{array}$ & Indikator & $\begin{array}{c}\text { No. Item } \\
\text { Pertanyaan }\end{array}$ \\
\hline \multirow[t]{2}{*}{$\begin{array}{c}\text { Minat } \\
\text { Mahasiswa } \\
\text { Memilih } \\
\text { Perguruan } \\
\text { Tinggi } \\
\text { Ekonomi } \\
\text { Islam }\end{array}$} & Individu & $\begin{array}{ll}- & \text { Motivasi } \\
- & \text { Latar belakang } \\
& \text { pendidikan } \\
- & \text { Gaya hidup } \\
- & \text { Cita-cita } \\
- & \text { Keyakinan } \\
& \text { terhadap nilainilai } \\
& \text { Islam } \\
\end{array}$ & $1 \mathrm{~s} / \mathrm{d} 5$ \\
\hline & Sosial- & $\begin{array}{ll}- & \begin{array}{l}\text { Sosialisasi dari } \\
\text { sekolah }\end{array}\end{array}$ & $6 \mathrm{~s} / \mathrm{d} 8$ \\
\hline
\end{tabular}




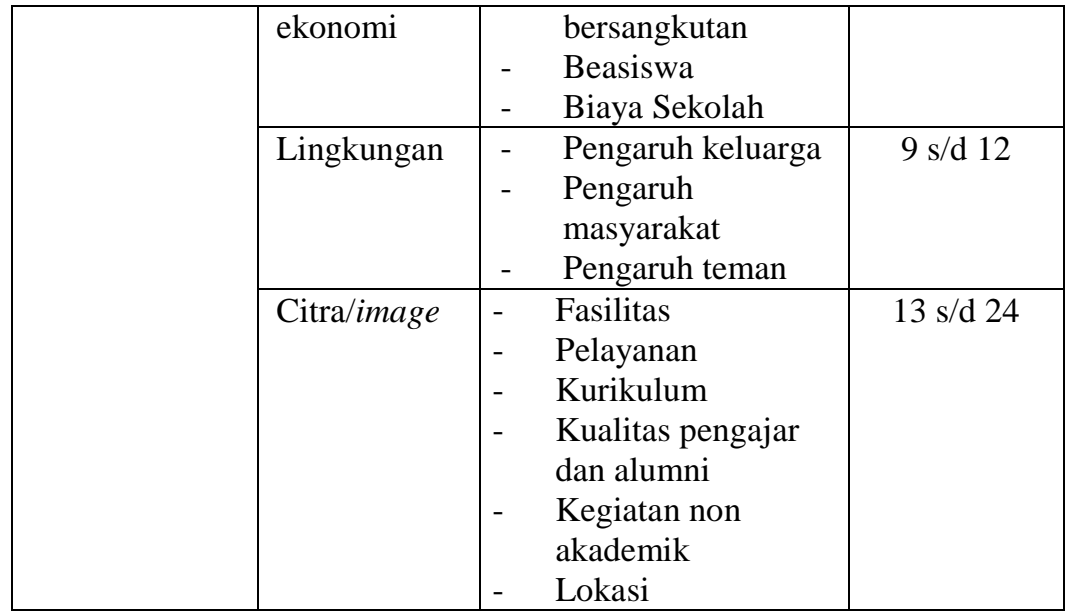

\section{Sumber: (Ali Hasan, 2002) dan (Sujanto, 2004)}

Tabel di atas menjelaskan tentang variabel penelitian, dimana variabel mandiri adalah minat mahasiswa memilih perguruan tinggi Ekonomi Islam. Sedangkan faktor-faktor yang mempengaruhi minta merupakan variabel turunan yang mempengaruhi minat. Masing-masing variabel turunan memiliki beberapa indikator terkait yang menjadi bahan analisis peneliti sebagai item pertanyaan dalam kuesioner.

\section{5. Skala Pengukuran}

Skala pengukuran yang digunakan dalam penelitian ini adalah skala guttman. Skala ini digunakan untuk mendapat jawaban tegas, yaitu "ya-tidak"; "benar-salah", dan lain-lain (Sugiyono, 2011, hal. 96). Skala dalam penelitian ini mempunyai dua interval, yaitu "ya" dan "tidak", dimana jawaban "ya" diberi skor 1 dan jawaban "tidak" diberi skor 0 .

\section{6. Analisis Data}

Sebelum kuesioner disebar kepada responden, peneliti terlebih dahulu melakukan uji validitas dan reliabilitas, agar setiap pertanyaan mudah dipahami dengan baik, sehingga menghasilkan jawaban yang sesuai dan tepat.

\subsubsection{Uji Validitas}

Validitas merupakan derajad ketepatan antara data yang sesungguhnya terjadi pada objek penelitian dengan data yang dapat dilaporkan oleh peneliti. Dengan demikian data valid adalah data "yang tidak berbeda" antara data yang dilaporkan oleh peneliti dengan data yang sesungguhnya terjadi pada obyek penelitian(Sugiyono, 2011, hal. 267). Uji validitas menunjukkan apakah kuesioner mempu mengukur apa yang harus diukur. Jika diukur dengan menggunakan software statistik SPSS, dan menghasilkan signifikansi di bawah nilai alfa yang dipersyaratkan, maka instrumen tersebut dinyatakan valid. Butir kuisioner dapat dikatakan valid manakala memiliki nilai komponen lebih besar atau sama dengan $50 \%(0,500)$. 


\subsubsection{Uji Reliabilitas}

Uji reliabilitas merupakan suatu kestabilan dan konsistensi responden dalam menjawab hal yang berkaitan dengan konstruk-konstruk pertanyaan yang merupakan dimensi suatu variabel dan disusun dalam bentuk kuesioner (Nugroho, 2005, hal. 79). Instrumen dinyatakan andal (reliable) jika menghasilkan ukuran yang konsisten apabila digunakan berulang kali, dan instrumen tersebut andal apabila menghasilkan nilai alpha cronbach > 0,06 (Trihendradi, 2012, hal. 304).

Setelah data yang diuji valid dan reliabel, peneliti melakukan analisis data dengan uji Chi-Square untuk menguji perbedaan antara frekuensi pengamatan dan frekuensi yang diharapkan (Trihendradi, 2012, hal. 198). Peneliti dalam mengolah data menggunakan software statistik SPSS 16.0 for windows, dengan taraf nyata 0,05 (5\%). Apabila nilai $C h i$ Square lebih besar dari tarif nyata $0,05(3,841)$, maka terdapat faktor yang mempengaruhi minat mahasiswa memilih perguruan tinggi Ekonomi Islam, sebaliknya apabila nilai Chi Squarelebih kecil dari tarif nyata 0,05 $(3,841)$, maka tidak memiliki pengaruh.

\section{BAB IV ANALISIS DAN PEMBAHASAN}

\subsection{Karakteristik Responden}

Penelitian ini mengambil jumlah responden sebanyak 81 mahasiswa dari total populasi angkatan 2011 dan 2012 sebanyak 413 mahasiswa. Karakteristik responden merupakan gambaran umum dari keadaan responden sebagai objek penelitian. Karakteristik tersebut dilihat dari jenis kelamin, usia, program studi, angkatan, asal daerah, pendidikan terakhir, kategori biaya pendidikan, pekerjaan orangtua, penghasilan orangtua per-bulan, dan uang saku mahasiswa per-bulan. Gambaran umum tersebut dipaparkan dalam tabel berikut:

\section{Grafik 4.1 Karakterisitk Responden Berdasarkan Jenis Kelamin}

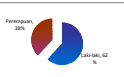


Dari grafik di atas, dapat kita lihat bahwa jumlah mahasiswa lakilaki sebanyak 50 responden atau $62 \%$ dan perempuan sebanyak 31 responden atau $38 \%$, dari hal tersebut dapat dianalisa bahwa jenis kelamin mempengaruhi pilihan perguruan tinggi, karena berhubungan dengan rencana karier seseorang setelah melalui pendidikan di perguruan tinggi, dimana cukup banyak bidang pekerjaan Ekonomi Islam bagi laki-laki.

Grafik 4.2 Karakterisitk Responden Berdasarkan Usia (1)=

\section{Sumber: Data primer yang diolah}

Grafik di atas menggambarkan rentang usia responden dari mahasiswa angkatan 2011 dan 2012. Mahasiswa dengan rentang usia 1619 tahun sebanyak 44 orang atau 54\%, sedangkan mahasiswa dengan rentang usia 20-23 tahun sebanyak 37 orang atau 46\%. Rentang usia tersebut tersebar di dua angkatan 2011 dan 2012, karena ada mahasiswa yang setelah kelulusan dari jenjang sekolah menegah atas tidak langsung mendaftar ke perguruan tinggi, melainkan bekerja atau mengikuti kursus singkat berbagai macam keahlian.

\section{Grafik 3.3Karakterisitk Responden Berdasarkan Program Studi}

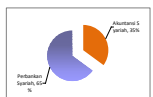




\section{Sumber: Data primer yang diolah}

Grafik yang menggambarkan program studi yang diambil dari sampel responden mahasiswa STEI SEBI angktan 2011 dan 2012 menunjukkan bahwa jumlah mahasiswa jurusan Perbankan Syariah lebih banyak, yakni $65 \%$ atau 53 mahasiswa daripada jurusan Akuntansi Syariah yang hanya $35 \%$ atau 28 mahasiswa. Pilihan jurusan tersebut dikatakan dapat mempengaruhi minat mahasiswa terhadap perguruan tinggi Ekonomi Islam.

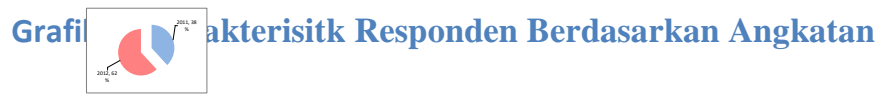

\section{Sumber: Data primer yang diolah}

Seperti telah dibahas sebelumnya, bahwa penelitian ini dibatasi pada mahasiswa angkatan 2011 dan 2012 yang telah memulai perkuliahan aktif di kampus STEI SEBI Bojongsari, Depok. Grafik tersebut mewakili jumlah mahasiswa angkatan 2012 yang memang lebih banyak, yakni sebesar $62 \%$ atau 50 mahasiswa yang menjadi responden, sedangkan angkatan 2011 sebesar $38 \%$ atau 31 mahasiswa. Hal tersebut juga menggambarkan perkembangan jumlah mahasiswa STEI SEBI yang meningkat dari tahun 2011 ke tahun 2012, yang dapat juga dikatakan bahwa minat mahasiswa terhadap Ekonomi Islam semakin meningkat.

Grafik 4.5 Karakterisitk Responden Berdasarkan Asal Daerah

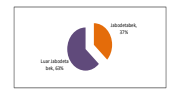


Grafik yang menggambarkan asal daerah dari responden di atas menunjukkan bahwa banyak mahasiswa yang berasal dari daerah luar Jabodetabek (Jakarta, Bogor, Depok, Tangerang, Bekasi) sebesar 63\% atau 51 mahasiswa. Daerah tersebut tersebar pada sebagian besar pulau di Indonesia, diantaranya Sumatera, Kalimantan, maupun Jawa Barat sampai Jawa Timur. Sedangkan mahasiswa yang berasal dari daerah Jabodetabek sebesar $37 \%$ atau 30 mahasiswa yang sebagian besar berasal dari Jakarta dan Depok. Hal tersebut dapat memperlihatkan bahwa asal daerah tidak berpengaruh signifikan terhadap minat memilih perguruan tinggi Ekonomi Islam.

\section{Grafik 4.6 Karakterisitk Responden Berdasarkan Pendidikan Terakhir}

\section{Sumber: Data primer yang diolah}

Pendidikan asal mahasiswa dapat dilihat dari grafik di atas, dimana banyak mahasiswa yang memiliki latar pendidikan Sekolah Menengah Atas (SMA) yang secara umum belum terdapat jurusan yang mengarah pada materi Ekonomi Islam, yakni sebesar 53\% atau 43 mahasiswa. Selebihnya berasal dari Sekolah Menegah Kejuruan (SMK) sebesar 23\% atau 19 mahasiswa, 14\% atau 11 mahasiswa dari Madrasah Aliyah (MA) baik negeri maupun swasta, dan $10 \%$ atau 8 mahasiswa berasal dari pendidikan pesantren. Dari data tersebut dapat dilihat bahwa latar belakang pendidikan yang sesuai tidak berpengaruh signifikan terhadap minat mahasiswa memilih perguruan tinggi Ekonomi Islam.

Grafik 4.7 Karakterisitk Responden Berdasarkan Kategori Biaya

\section{Pendidikan}


Biaya pendidikan cukup menentukan minat mahasiswa memilih perguruan tinggi Ekonomi Islam, dari grafik di atas dapat dilihat bahwa banyak mahasiswa yang mendapat beasiswa penuh $100 \%$ yakni sebesar $68 \%$ atau 55 mahasiswa, beasiswa $50 \%$ sebanyak $28 \%$ atau 23 mahasiswa, selebihnya $25 \%$ dan reguler masing-masing $3 \%$ dan $1 \%$ atau 2 dan 1 mahasiswa. Data tersebut menunjukkan hal yang cukup signifikan, dimana sangat sedikit sekali mahasiswa yang kuliah di STEI SEBI dengan biaya reguler, hanya sebesar 1\%. Maka beasiswa dirasa merupakan faktor yang cukup mempengaruhi minat mahasiswa memilih perguruan tinggi Ekonomi Islam.

\section{Grafik 4.8 Karakterisitk Responden Berdasarkan Pekerjaan Orangtua}

\section{Sumber: Data primer yang diolah}

Grafik tersebut menunjukkan karakterisitik responden berdasarkan pekerjaan orangtua. Dimana pekerjaan yang banyak menjadi profesi orangtua mahasiswa ada pada data pekerjaan lainnya, yakni sebesar $42 \%$ atau 34 responden, jenis spesifikasi kategori tersebut sebagaian besar profesinya adalah petani dan buruh lepas. $27 \%$ atau 22 responden sebagai wirausaha, $22 \%$ atau 18 responden sebagai pegawai swasta, dan terakhir yang paling kecil adalah pegawai negeri sipil sebesar 9\% atau 7 responden. Hal tersebut menunjukkan bahwa terdapat hubungan antara beasiswa dengan jenis pekerjaan orangtua yang rata-rata merupakan jenis pekerjaan dengan penghasilan menegah ke bawah.

Grafik 4.9Karakterisitk Responden Berdasarkan Penghasilan

\section{Orangtua}

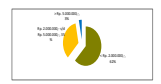


Berdasarkan grafik di atas, terlihat bahwa penghasilan orangtua berbanding lurus dengan jenis pekerjaannya, dimana jenis pekerjaan yang memberikan penghasilan kategori menegah ke bawah, yaitu kurang dari Rp. 2.000.000,- sebesar $62 \%$ atau 50 responden. Sedangkan orangtua dengan penghasilan antara Rp. 2.000.000,- sampai dengan Rp. $5.000 .000,-$ sebesar $35 \%$ atau 28 responden. Selebihnya yang berpenghasilan di atas Rp. 5.000.000,- hanya 3\% atau 3 responden. Penghasilan orangtua mempengaruhi minat mahasiswa memilih STEI SEBI dengan mengusahakan kemampuan untuk mendapatkan beasiswa. Sehingga beasiswa menjadi faktor yang cukup signifikan.

Grafik 4.10 Karakterisitk Responden Berdasarkan Uang Saku PerBulan

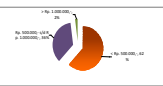

\section{Sumber: Data primer yang diolah}

Grafik di atas menunjukkan jumlah uang saku yang didasarkan pada jumlah pengeluaran rata-rata mahasiswa di STEI SEBI sehariharinya dalam satu bulan. 62\% atau 50 mahasiswa dengan uang saku kurang dari Rp. 500.000,- dan 36\% atau 29 mahasiswa mendapat uang saku Rp. 500.000,- sampai dengan Rp. 1.000.000,-, selebihnya $2 \%$ atau 2 mahsiswa menadapat uang saku diatas Rp. 1.000.000,-. Jumlah uang saku berhubungan pula dengan beasiswa, jenis pekerjaan orangtua dan jumlah penghasilan orangtua. Dimana pengaruhnya terhadap minat cukup berpengaruh.

\subsection{Analisis Uji Validitas dan Reliabilitas}

\subsubsection{Uji Validitas}

Pengujian ini dilaksanakan dengan menggunakan Correlation bivariate. Pengujian validitas setiap pertanyaan menggunakan item, yaitu mengkolerasikan skor tiap butir dalam tabel telah ditunjukan skor totalnya, yang merupakan skor tiap butir. Butir kuisioner dapat dikatakan valid manakala memiliki nilai komponen lebih besar atau sama dengan $50 \%(0,500)$. Dalam pengolahannya peneliti menggunakan SPSS versi 
16.0for windows. Pada tabel dibawah ini dapat dilihat hasil dari uji validitas pada setiap item-item variabel dalam penelitian ini.

Tabel 0.4Hasil Uji Validitas

\begin{tabular}{|c|c|c|c|}
\hline No. & Item Pertanyaan & Komponen & Status \\
\hline \multicolumn{4}{|c|}{ Faktor Individu (I) } \\
\hline 1 & I. 1 & 0,807 & Valid \\
\hline 2 & I. 2 & 0,914 & Valid \\
\hline 3 & I. 3 & 0,925 & Valid \\
\hline 4 & I.4 & 0,359 & Tidak Valid \\
\hline 5 & I.5 & 0,734 & Valid \\
\hline 6 & I. 6 & $-0,428$ & Tidak Valid \\
\hline 7 & I.7 & 0,638 & Valid \\
\hline \multicolumn{4}{|c|}{ Faktor Sosial-Ekonomi (S.E) } \\
\hline 8 & S.E.1 & 0,633 & Valid \\
\hline 9 & S.E.2 & 0,867 & Valid \\
\hline 10 & S.E.3 & 0,741 & Valid \\
\hline \multicolumn{4}{|c|}{ Faktor Lingkungan/Budaya (L) } \\
\hline 11 & L.1 & 0,788 & Valid \\
\hline 12 & L. 2 & 0,706 & Valid \\
\hline 13 & L. 3 & 0,855 & Valid \\
\hline 14 & L. 4 & 0,909 & Valid \\
\hline 15 & L.5 & 0,432 & Tidak Valid \\
\hline \multicolumn{4}{|c|}{ Faktor Citra/Image (C) } \\
\hline 16 & C. 1 & 0,659 & Valid \\
\hline 17 & C. 2 & 0,795 & Valid \\
\hline 18 & C. 3 & 0,889 & Valid \\
\hline 19 & C. 4 & 0,771 & Valid \\
\hline 20 & C. 5 & 0,929 & Valid \\
\hline 21 & C. 6 & 0,887 & Valid \\
\hline 22 & C. 7 & 0,458 & Tidak Valid \\
\hline 23 & C. 8 & 0,851 & Valid \\
\hline 24 & C.9 & 0,863 & Valid \\
\hline
\end{tabular}




\begin{tabular}{|c|c|c|c|}
\hline 25 & C. 10 & 0,843 & Valid \\
\hline 26 & C. 11 & 0,775 & Valid \\
\hline 27 & C. 12 & 0,768 & Valid \\
\hline 28 & C. 13 & 0,773 & Valid \\
\hline
\end{tabular}

Sumber: Data primer yang diolah

Dari tabel di atas, terdapat item pertanyaan yang tidak valid pada variabel individu4 (I4) dan individu6 (I6), dimana nilai komponennya di bawah standard $(0,500)$ yakni 0,359 dan - 0,428. Item yang tidak valid juga terdapat pada variabel lingkungan5 (L5) yakni dengan nilai komponen sebesar 0,423, serta pada item Citra7 (C7) dengan nilai komponen 0,458 .

\subsection{Uji Reliabilitas}

Reliabilitas merupakan alat ukur untuk mengukur suatu kuesioner yang merupakan indikator dari suatu variabel. Dengan bantuan program SPSS, dapat memberikan fasilitas untuk mengukur reliabilitas dengan uji statistik cronbach Alpha $(\alpha)$. Suatu variabel dikatakan reliabel jika memberikan nilai cronbach Alpha> 0,60. Dalam pengolahannya peneliti menggunakan SPSS 16.0 yang dipaparkan dalam tabel berikut ini :

\section{Tabel 0.5Hasil Uji Reliabilitas Faktor Individu, Sosial-ekonomi, Lingkungan dan Citra}

Reliability Statistics

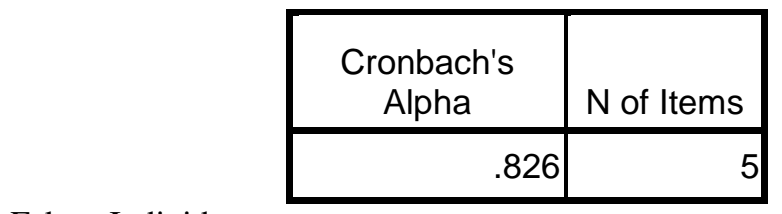

Faktor Individu

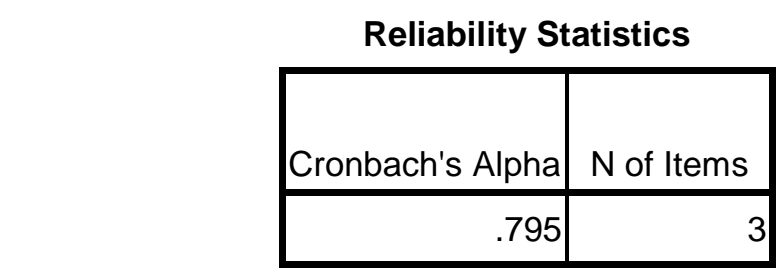

Faktor Sosial-ekonomi 


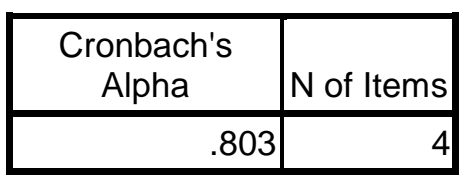

Faktor Lingkungan/Budaya

Reliability Statistics

\begin{tabular}{|r|r|}
\hline $\begin{array}{c}\text { Cronbach's } \\
\text { Alpha }\end{array}$ & N of Items \\
\hline .768 & 12 \\
\hline
\end{tabular}

Faktor Citra

\section{Sumber: Data primer yang diolah}

Dari perhitungan diatas, maka dapat diperoleh bahwa untuk empat variabel memiliki nilai cronbach Alpha $>0,60$. Dengan demikian, maka 24 butir pertanyaan tersebut reliabel untuk mengukur reliabilitas yang mempengaruhi minat mahasiswa terhadap perguruan tinggi Ekonomi Islam.

\subsection{Analisis Uji Chi-Square}

Untuk mengetahui adanya hubungan minat mahasiswa memilih perguruan tinggi Ekonomi Islam, dapat diketahui dengan menggunakan uji Chi Square(Khi-Kuadrat) dengan tarif nyata 0,05. Apabila nilai $C h i$ Squarelebih besar dari tarif nyata $0,05(3,841)$, maka terdapat faktor yang mempengaruhi minat mahasiswa memilih perguruan tinggi Ekonomi Islam, sebaliknya apabila nilai Chi Squarelebih kecil dari tarif nyata 0,05 $(3,841)$, maka tidak memiliki pengaruh.

Faktor yang mempengaruhi minat mahasiswa memilih perguruan tinggi Ekonomi Islam dilambangkan dengan angka 1 dan untuk faktor yang tidak memiliki pengaruh terhadap kepuasan kerja dilambangkan dengan 0. Adapun faktor yang memiliki pengaruh terhadap minat mahasiswa adalah faktor individu, sosial-ekonomi, lingkungan/budaya, serta citra/imagekampus.

Untuk membedakan hasil Chi Squarepada tabel yang memiliki faktor yang berpengaruh terhadap minat mahasiswa dan yang tidak memiliki pengaruh, penulis membedakan dengan memberi warna yang berbeda. Tabel yang mempunyai pengaruh terhadap minat mahasiswa ditunjukkan oleh warna biru, sedangkan untuk tabel yang tidak memiliki pengaruh diberi warna merah. Berikut adalah hasil analisis Chi-square : 
Tabel 0.6

$\mathrm{X}^{2}$ Hitung yang Lebih Besar dari $\mathrm{X}^{2}$ Tabel

\begin{tabular}{|c|c|c|}
\hline No. & Faktor & $\mathbf{X}^{\mathbf{2}}$ Hitung \\
\hline $\mathbf{1}$ & I2 & 25,998 \\
\hline $\mathbf{2}$ & I3 & 25,287 \\
\hline $\mathbf{3}$ & I4 & 25,287 \\
\hline $\mathbf{4}$ & SE1 & 8,022 \\
\hline $\mathbf{5}$ & C8 & 7,227 \\
\hline
\end{tabular}

\section{Sumber: Data Primer yang Diolah}

Berdasarkan data tersebut, diperoleh lima faktor yang mempengaruhi minat mahasiswa memilih perguruan tinggi Ekonomi Islam, yaitu:

1. Faktor Individu2 (I2)

Ekonomi Islam

2. Faktor Individu3 (I3)

Ekonomi Islam

3. Faktor Individu4 (I4)

Ekonomi Islam

: Motivasi menjadi ahli

: Keinginan mempelajari

: Cita-cita sebagai ahli

4. Faktor Sosial-ekonomi1 (SE1) : Beasiswa

5. Faktor Citra8 (C8)

: Prospek karier yang baik.

Data yang diperoleh dari responden menunjukkan bahwa sebagian besar mahasiswa memiliki minat terhadap perguruan tinggi Ekonomi Islam karena motivasi, keinginan dan cita-cita menjadi ahli di bidang Ekonomi Islam, yakni mencapai angka persentase yang sama, 93,83\% atau sebanyak 76 mahasiswa dari total 81 mahasiswa sebagai responden. Persentase tersebut menghasilkan nilai $\mathrm{X}^{2}$ hitung sebesar 25,998 untuk I2; 25,287 untuk I3 dan I4. Ketiga angka tersebut merupakan tiga indikator dengan angka tertinggi.

Sementara itu, indikator sosial-ekonomi juga mempengaruhi minat mahasiswa, yakni dengan kesempatan mendapat beasiswa, terutama kesempatan yang cukup besar untuk mendapat beasiswa penuh 100\%, walaupun diantaranya ada beasiswa $50 \%$ dan $25 \%$ yang bisa didapatkan berdasarkan serangkaian seleksi. Angka persentase untuk faktor beasiswa sebesar $48,15 \%$ atau sebanyak 39 mahasiswa dari 81 mahasiswa, dengan nilai $\mathrm{X}^{2}$ hitung sebesar 8,022 .

Selain itu indikator citra/image kampus juga cukup mempengaruhi minat mahasiswa, dengan nilai $\mathrm{X}^{2}$ hitung sebesar 7,227 dengan persentase angka 38,27\% atau sebanyak 31 dari 81 mahasiswa. Angka tersebut cukup jauh dibandingkan faktor motivasi, keinginan dan cita-cita menjadi ahli di bidang Ekonomi Islam. Dengan demikian, status akreditasi pun tidak signifikan berpengaruh terhadap minat mahasiswa, karena mahsiswa tertarik dengan ilmu ekonomi Islam itu sendiri yang 
secara umum di Indonesia sedang terus mengalami perkembangan setiap tahunnya

\section{BAB V PENUTUP}

\subsection{Kesimpulan}

Berdasarkan penelitian dan analisis yang telah dilakukan, maka dapat disimpulkan bahwa.

a. Dari 24 indikator yang diujikan, ada lima indikator yang mempengaruhi minat mahasiswa memilih perguruan tinggi Ekonomi Islam, yakni motivasi, keinginan mempelajari Ekonomi Islam, cita-cita menjadi ahli Ekonomi Islam, beasiswa, dan prospek karier yan baik. Dinyatakan dengan nilai $\mathrm{X}^{2}$ hitung yang lebih besar dari nilai $\mathrm{X}^{2}$ tabel.

b. Indikator motivasi menjadi ahli Ekonomi Islam menjadi indikator dengan poin paling besar diantara kelima indikator tersebut. Dapat dikatakan minat memilih perguruan tinggi Ekonomi Islam memang murni karena ketertarikan terhadap ilmu Ekonomi Islam itu sendiri.

c. Indikator beasiswa menjadi indikator yang cukup mempengaruhi minat mahasiswa memilih perguruan tinggi Ekonomi Islam, hal tersebut terbukti dari lebih banyak jumlah mahasiswa penerima beasiswa baik itu beasiswa $100 \%, 50 \%$ maupun $25 \%$.

d. Indikator citra/image STEI SEBI yang baik juga cukup mempengaruhi minat mahasiswa memilih perguruan tinggi Ekonomi Islam, hal tersebut dapat dilihat dari nilai $\mathrm{X}^{2}$ hitung yang lebih besar dari $\mathrm{X}^{2}$ tabel, yaitu 7,227.

e. Faktor lingkungan tidak memberikan faktor yang signifikan terhadap minat memilih perguruan tinggi Ekonomi Islam. Indikator dari faktor lingkungan tersebut adalah dukungan orangtua, keluarga/kerabat dekat, teman, dan lingkungan masyarakat.

\subsection{Saran}

Adapun saran yang dapat peneliti tuliskan dan dapat menjadi rujukan penelitian berikutnya maupun saran untuk pihak terkait adalah sebagai berikut.

a. Poin daya tarik tersebut diantaranya kesempatan mendapat beasiswa bagi calon mahasiswa berprestasi, serta meningkatkan kualitas pengajar, kurikulum, maupun sarana dan prasarana, karena ilmu tentang Ekonomi Islam itu sendiri lah yang menjadi daya tarik paling besar bagi calon mahasiswa.

b. Konsep pemasaran jasa STEI SEBI dapat ditingkatkan lagi, terutama poin pada sosialisasi melaui relasi, maupun sosialisasi 
kepada orangtua yang sedikit banyak memahami tentang ekonomi Islam baik dari kalangan akademisi maupun praktisi.

c. Bagi penelitian selanjutnya, diharapkan dapat meneliti permasalahan terkait SDM Ekonomi Islam secara luas dan mendalam, objek penelitian tidak hanya dilakukan di satu perguruan tinggi, melainkan di berbagai perguruan tinggi maupun sekolah setingkat SMA/SMK yang juga konsen dalam ranah menghasilkan SDM Ekonomi Islam.

\section{DAFTAR PUSTAKA}

Abdul Rahman Saleh, d. (2004). Psikologi Islam. Jakarta: Raja Grafindo Persada.

Agustianto. (2013, Juli). Diambil kembali dari Agustianto Centre: http://www.agustiantocentre.com/

Ali Hasan, S. M. (2002). Marketing. Yogyakarta: Media Pressindo.

Ali Sakti, M. E. (2007). Analisis Teoritis Ekonomi Islam (Jawaban Atas Kekacauan Ekonomi Modern). Jakarta: Paradigma \& Aqsa Publishing.

Amalia, E. (2012). Potret Pendidikan Ekonomi Islam di Indonesia. Depok: Gramata Publishing.

Arief. (2007). Pemasaran Jasa dan Kualitas Pelayanan. Malang: Bayumedia Publishing.

Bambang Prasetyo, L. M. (2007). Metode Penelitian Kuantitatif. Jakarta: Raja Grafindo Persada.

Bank Indonesia. (Desember, 2012). Statistik Perbankan Syariah, 1.

Bank Indonesia. (2013). Outlook Perbankan Syariah 2013. Outlook Perbankan Syariah $2013,3$.

Bank Indonesia. (2013, Maret). Statistik Perbankan Syariah Indonesia. Diambil kembali dari http://www.bi.go.id

Dwiastuti, R. (2012). Ilmu Perilaku Konsumen. Malang: UB Press.

Hawkins, B. (2001). Pemasaran. Jakarta: Salemba Empat.

Hurlock, E. B. (1999). Psikologi Perkembangan. Jakarta: Pearson Education.

Kotler, P. (2002). Manajemen Pemasaran 1. jakarta: PT. Prehalindo.

Kotler, P. (2009). Manajemen Pemasaran. Indonesia: PT. Indeks.

Lupiyoadi, R. (2006). Manajemen Pemasaran Jasa. Jakarta: PT. Salemba Empat.

Nasional, D. (2007). Kamus Besar Bahasa Indonesia. Jakarta.

Nugroho, B. A. (2005). Strategi Jitu Memilih Metode Statistik Penelitian dengan SPSS. Yogyakarta: Andi Offset.

Payne, A. (2000). The Essence of Services Marketing. Indonesia: ANDI dan Pearson Education Asia.

Riduwan, M. (2007). Skala Pengukuran Variabel-variabel Penelitian. Bandung: Alfabeta.

Saladin, D. (2003). Intisari Pemasaran dan Unsur-unsur Pemasaran. Bandung: Linda Karya.

Santoso, S. (2004). SPSS Statistik Multivariat. Jakarta: PT. Gramedia.

SEBI, STEI. (2012). Buku Panduan Penyusunan Tugas Akhir. Depok.

Sekolah Tinggi Ekonomi Islam SEBI. (2013, Juni). Dipetik Juni 2013, dari http://www.sebi.ac.id 
Sugiyono, P. D. (2011). Metode Penelitian Kuantitatif dan Kualitatif dan R \& $D$. Bandung: Alfabeta.

Sujanto, D. A. (2004). Psikologi Umum. Jakarta: Bumi AKsara.

Sunarto. (2002). Psikologi Perkembangan. Jakarta: Raja Grafindo Persada.

Supranto, J. (2004). Analisis Multivariat Arti dan Interpretasi. Jakarta: PT. Rineka Cipta.

Trihendradi. (2012). Step By Step SPSS. Yogyakarta: Andi Offset.

Wijaja, A. (2005). Memahami Konsep Value Added dan Value Nased Management. Jakarta: Havarindo.

Zeithaml, V. (2003). Service Marketing. Indonesia: The Mc. Graw Hill Companies. 